\title{
Jews as Cossacks: A Symbiosis in Literature and Life
}

\author{
Gennady Estraikh
}

In the compartmentalized Soviet world of letters, Yiddish literati were the principal holders of the "license" for portraying Jews. Therefore, translations of their works also prevailed among Russian books on Jewish aspects of the war. Such writers as Ikhil Falikman and Mikhail Lev focused on writing novels of wartime Jewish experiences and the Sovetskii Pisatel' (Soviet Writer) publishing house, the main Soviet producer of belles-letters, kept releasing Yiddish and Russian versions of their books. ${ }^{1}$ Motifs of wartime friendship between Jews and non-Jews dominated the literary and journalistic production authored by Yiddish writers, such as Falikman and Lev, who in the 1940s belonged to the milieu of the Jewish Anti-Fascist Committee, were destined to survive the Stalinist suppression, and regrouped around the Moscow literary journal Sovetish heymland (Soviet Homeland), established in $1961 .^{2}$

Trying to keep their balance walking along the peoples' friendship tightrope, writers populated their works with "good" and "bad" fictional embodiments of various ethnic groups. The lack of the "balanced approach" ingredient in the recipe for a socialist realist work might be construed as nationalism. Writers were reminded about the need for balance, for instance, in Nikita Khrushchev's speech of March 8, 1963 to the leading Soviet cultural figures. In his critique of Evgenii Evtushenko's poem "Babii Iar," the Soviet leader argued that the poet failed to "show political maturity" and represented "things as if only Jews [had been] the victims of the fascist atrocities." Setting an example of an ideologically correct approach, Khrushchev recalled a certain Kogan, a former Kiev functionary of the Young Communist League, who was among the German POWs captured during the Stalingrad battle. 
An interpreter with the Field Marshal von Paulus's staff, Kogan exemplified a Jewish traitor. ${ }^{3}$ In this climate, writers tended to show in their works both Jewish and non-Jewish Nazi collaborators. Thus, a balanced set of villains and heroes was one of the factors that made possible the publication of Anatolii Rybakov's Russian novel Heavy Sand; its Yiddish translation promptly appeared in Sovetish heymland (issues 4, 5 and 6, 1979). ${ }^{4}$ In his novel The Time, Aron Vergelis, editor of Sovetish heymland, went so far as to describe a partnership among a Zionist agent, a Russian Nazi collaborationist, and the most publicized adventurer of Nazi Germany, Otto Skorzeny. ${ }^{5}$

Jewish heroism, too, had to be balanced against non-Jewish heroism. In the late 1940s and early 1950s, leading Yiddish writers were accused, and some of them executed, for "spreading the notion" that the Jewish people "displayed supposedly exceptional heroism in the struggle against fascism." 6 Soviet Yiddish writers and editors would not forget this lesson, though their positive characters, most notably Red Army soldiers and officers, always, even before the repression, appeared as convinced internationalists. This chapter focuses on the "friendship of Jews and Cossacks" as one of the directions of prewar propaganda campaigns and a recurring trope in writings devoted to the Great Patriotic War.

Traditionally, Jews considered any representatives of the Don, Kuban, or other communities of warriors-cum-farmers-who were predominantly Russian, but before the revolution belonged to a special social estate, enjoyed vast autonomy, and served in separate cavalry detachments of the army-as enemies. On numerous occasions the tsarist government used Cossack units as a repressive force. In the Jewish press and other contemporary reports, particularly during the First World War, they usually appeared as bloodthirsty, wild beings, who found pleasure in violence against Jews. "When the Russian army passed through many towns and villages, especially when there were Cossacks, bloody pogroms took place." ${ }^{7}$ During the Civil War, Cossacks also acted as perpetrators of anti-Jewish pogroms, which essentially continued the same wave of mass violence. ${ }^{8}$

Soviet Yiddish writers presented a different pattern of Cossack-Jewish relations. Thus, for Zalman Lifshits, the protagonist of Khaim Melamud's novel In the Beginning of Summer, a seminal event took place five years before 
the war, during a competition between collective farmers from the Jewish colony (village) Novozlatopol (Nayzlatopol in Yiddish), in southeastern Ukraine, with their counterparts from the Don Cossack stanitsa (village) Tsimlianskaia. Zalman, a young chairman of a Jewish collective farm, was born and grew up in the Jewish colony, established in the 1840s as part of the tsarist government's efforts to cultivate among Jews a "useful" segment of the population. The years of military service in the Red Army made Zalman an experienced cavalryman. In Tsimlianskaia, however, people did not know about his atypically Jewish background, and Zalman's riding skills astonished the Don Cossacks. As a sign of their appreciation (and good sportsmanship), they decided to include him on the list of local Cossacks, and to present him with a Cossack uniform and a sword. That episode determined Zalman's fate during the war. When, in the summer of 1941, following the beginning of the German-Soviet (or "Great Patriotic") War, Zalman was drafted into the Red Army, he wound up in a Cossack unit.

It was not easy to be the only Jewish soldier among hereditary warriors recruited from Cossack stanitsas. Andrei, a soldier from the same squadron, singled out Zalman for his Jewish name and for having questionable Cossack credentials. Zalman, however, tolerated Andrei's jokes, realizing that these quips entertained other soldiers in the difficult days of retreat. Still, he was surprised when Andrei chose him as a partner in a reconnaissance assignment-to get to a forest situated a couple kilometers from the frontline trenches, hide there, and monitor the situation on a highway. It was an ill-fated expedition: the highway was full of German tanks, cars, and motorcycles; both soldiers found themselves surrounded by the enemy troops and understood that they would be taken as POWs. Andrei, who heard Zalman speaking Yiddish while sleeping, warned him to be careful and suggested that he use a non-Jewish name. Thus, Zalman became Zakir, a Tartar. Andrei approved this choice-first, Zalman "looked like a Tartar"; second, even Grigorii Melekhov, the protagonist of Mikhail Sholokhov's novel And Quiet Flows the Don, had Tartar blood. Ultimately, the uniform saved Zalman, because not one of the Nazis and their collaborators expected to find a Jew among the captured Cossacks.

Following some period of incarceration in a camp, Andrei and Zalman seized the moment to escape when their group of POWs was marching westward, dispatched to Germany as slave labor. Freedom came with a price: Zalman fell into a pit and broke a leg. Andrei did not leave Zalman behind; 
he put him back on his feet by boiling for him a healing mixture of pine tar, needles of spruce, bark of birch, and oak leaves. Eventually, the two friends joined a Czech partisan group, and thus ended the Cossack-Jewish storyline, which appears as flashbacks in the main narrative, whose two-dimensional characters ("good" Jews and non-Jews and "bad" Jews and non-Jews) interact mainly in the summer of 1945, after Zalman's demobilization.

The Cossack-Jewish trope appears also in the writings of Shmuel Gordon (1909-1998), a writer of the same generation as Khaim Melamud (1907-1993). ${ }^{9}$ In one of Gordon's stories, several Jewish collective farmers from Crimea survived the German occupation, hiding in a Kuban Cossack stanitsa. ${ }^{10}$ Like Melamud's Zalman Lifshits, the central character of Gordon's other story entitled "A Fruit from the Tree of Life," the Jewish collective farmer Shiye-Mikhl Royz, became a heroic soldier in a Cossack division. ${ }^{11}$ In the style of Sholem Aleichem's Tevye the dairyman, Shiye-Mikhl the cavalry man tended to talk to himself about urgent problems of his life:

The Germans have concocted about us, Jews, more calumnies than the number of stars in the sky. One of the calumnies is that we, Jews, are cowards. I myself have seen so many surrendered Germans with raised hands and with faces pale as death. I asked a few of them: tell me, feed my curiosity, did you have the occasion to see an armed Jew with raised hands? Did you? They answered that no, they didn't. Can you see now who the cowards are-Germans or Jews? ${ }^{12}$

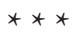

It is no coincidence that both Melamud and Gordon decided to portray their soldiers of the Cossack divisions as dwellers in Jewish villages. Partly, it had to do with their own involvement in the lives of the five Jewish national districts, which before the war existed in the European part of the Soviet Union. Melamud used to live in Novozlatopol, the administrative center of one of the districts, where he served as editor of the local Yiddish newspaper and wrote his early literary works. Although Gordon was a Moscow dweller, he visited Jewish villages many times, particularly in Crimea, and developed a name for himself as a writer on Jewish colonization. More important was the role of the Jewish peasants in the Soviet and (partly) non-Soviet model of contemporary Jewish life. To many enthusiasts of Jewish nation-building 
through agricultural colonization, the Soviet Union was a happy place, particularly as the design of Soviet Jewish territorial units began to come into view. According to Boruch Glazman, the American Yiddish prose writer, the Soviet Jewish agricultural colonization "is a great joy for all of us, because here also our life is being normalized, because a peasant class is being created among Jews - and not only in the Soviet Union but among the whole Jewish people; a peasant class that must bring new freshness and new content in our lives."13

"Normalization" meant making Jews "productive," economically independent, and physically strong. Jews, particularly of older generations, often considered Sovietization as compliance with goyish-rather than simply radically new-moral principles. As I contended elsewhere, this perception was natural for people who lived in a binary world where "Jewish" meant comme il faut, "correct," whereas goyish was a generic term for deviation from the norms accepted in Jewish society. ${ }^{14}$ Cossackness represented the ultimate goyishness, combining its positive and negative stereotypes. In the poem "Buy cigarettes!" (an allusion to Herman Yablokoff's popular song "Papirosn"), by the American Yiddish poet Malka Lee, a young Jewish female street vendor is sexually attracted to a Cossack whose "lion's eyes" undressed her while she was patting his horse like her "grandfather's tephillin." ${ }^{15}$ Significantly, Cossacks were antipodes of the stereotypically feeble dwellers of the shtetl, which had been written off by modernizers of various hues as a bastion of backwardness and a dead weight on the modern economy. The historian Yisroel Bartal describes the influence of the Cossack model upon the outlook and behavioral patterns of Zionists who moved to Palestine in the beginnings of the twentieth century. ${ }^{16}$

The appeal of Cossackness to Jewish communists found its best-known expression in Isaac Babel's literary portrayals of the Civil War. Babel adopted the Cossack hero, although the "historical Cossacks were enemies of his people." ${ }^{17}$ During the Civil War, some Jews joined the Chervone (Red) Cossacks military units, formed in Ukraine to fight on the side of the Bolsheviks. Several Jewish "Red Cossacks," such as Dmitrii Shmidt (David Gutman), Semen Turovskii, Mikhail Zyuk (Nekhamkin), and Il'ia Dubinskii became senior commanding officers of the Soviet cavalry corps. ${ }^{18}$ The Cossack model again played a role in the 1920s and 1930s, during the Soviet Jewish colonization drive, when thousands of shtetl dwellers resettled to Crimea, southeastern areas of Ukraine, and, from 1928, to 
Birobidzhan. The migrants had to be brave and strong "like Cossacks" in order to overcome the momentous difficulties of rebuilding their lives in the new, often hostile environment. Their trailblazing endeavors also had to become an important factor in fighting antisemitism. Special excursions to the colonies would be organized in order to convince non-Jewish citizens that the Jewish population had thousands of real toilers, similar to all other hardworking peasants. ${ }^{19}$

The Cossack topic found its place also in literary portrayals of Jewish life in Birobidzhan. Viktor Fink, who in the early 1930s wrote the Russian play Novaia rodina (New homeland), included in its dramatis personae positive and negative characters representing three groups of the Birobidzhan population-Jews, Cossacks, and Koreans-and reinforced the positive characters' brotherhood through mixed marriages, such as Jewish-Cossack and JewishKorean. Emanuil Kazakevich, whose 1932 poetic collection Birebidzhanboy (Birobidzhan construction) marked the beginning of Yiddish belles-lettres publishing in that part of the world, portrayed the celebrations of May 7, 1934-when the Far Eastern territory was granted the status of the Jewish Autonomous Region-as an interethnic event, which was welcomed also by the local Amur Cossacks. ${ }^{20}$ To all appearances, some local Cossacks did hope that the Jewish resettlement would facilitate the rebuilding of their habitat, devastated by the Civil War. ${ }^{21}$

Khaim Melamud did not invent the Cossack-Jewish competition. Indeed, in 1936 a group of Jewish collective farmers had won the contest in Tsimlianskaia, and their success was immortalized in numerous articles and stories, while the German Jewish writer Lion Feuchtwanger, who visited the Soviet Union in 1937, "was told of big, friendly contests between non-Jewish and Jewish settlements in the Ukraine, in the Crimea, and in the region of the Don. Don Cossacks told me that it was not the fact that the Jews had beaten them in agricultural competition which had overcome their former mistrust, but that the Jews had proved themselves to be the better riders."22

On April 27, 1936, six representatives of the Novozlatopol district arrived at the old stanitsa of Tsimlianskaia, today the town of Tsimliansk, about 300 kilometers from Rostov-on-Don. The place was best known for its wine, mentioned in Alexander Pushkin's poetic novel Eugene Onegin. During the 
Civil War, Tsimlianskaia was one of the centers of Cossack resistance to the Soviet regime. In 1919, when the Bolsheviks conducted the "decossackization," or, the campaign of merciless suppression of resistance in that area, the Soviet tribunal established in Tsimlianskaia oversaw the execution of hundreds of people. ${ }^{23}$

The reasons for sending the Jewish delegation to Tsimlianskaia went well beyond routine propaganda exercises orchestrated countrywide on the eve of the May Day proletarian holiday. First, the competition and the press campaign around the visit had to demonstrate the momentous achievements of Jewish collective farmers, and that by this time they had nothing in common with the "parasitic" shtetl dwellers, who attracted ridicule and violence. To a considerable degree, the Soviet regime further developed the tsarist government's strategy of (to use the term made current by Benjamin Nathans) "selective integration," or, the process of gradual dispersing of certain, most notably "productive," categories of Jews into the broader society. ${ }^{24}$ In 1926, a strategic program had divided the Jewish population into two groups: proletarians and other productive cohorts who should take a short cut to socialism and all but certain assimilation, and "non-productive elements" who were encouraged to settle in rural areas, where their route to integration would involve the stage of consolidation into a socialist Jewish nation of toilers. ${ }^{25} \mathrm{~A}$ decade later, Soviet ideologists sought to show the accomplishments of their social engineering.

Second, Cossack readiness to forge a friendship with Jews had to indicate their radical transformation, proof that years of efforts to win them over had achieved success. The timing of sending the Jewish delegation was carefully chosen by the propaganda apparatus: on April 20, 1936, a week before the Jewish delegation's arrival in Tsimlianskaia, a decree issued by the Soviet government hailed the socialist transformation of the Cossacks and, essentially, absolved them of their sins of fighting against the Red Army during the Civil War. According to the decree, Cossacks were no longer debarred from being drafted into the Red Army. Moreover, that year five existing cavalry divisions of the Red Army were converted into Cossack ones. ${ }^{26}$

Shmuel Godiner, a leading Yiddish prose writer in the pre-war Soviet Union (killed in action in 1941), paid much attention to the competition, authoring two documentary stories-with strong elements of "mythic realism"-about the Cossack-Jewish fraternization in the spring of $1936 .{ }^{27}$ The first of the two pamphlets came out in Russian in July 1936, hot on the heels 
of the events, whereas the second story, published in Yiddish in 1939, was more fictionalized. In the spirit of the new relations between Germany and the Soviet Union, the 1939 story did not contain anti-fascist rhetoric, whereas the 1936 version condemned the "ugly snout of Germany's chauvinist fascism;" ${ }^{28}$ an old Cossack was happy to see that Jews could be fine swordsmen and, mentioning the fascists, suggested that "we'll together chop off [their] heads." ${ }^{29}$

The winner of the competition, Matvei (Motl) Berdyshev, became the prototype for Melamud's Zalman Lifshits. Like Lifshits, Berdyshev chaired one of the Jewish collective farms. Godiner's chronicle does not mention that any Jewish rider had been included on the list of local Cossacks, but it contains a story of a Cossack uniform given as a present. It was a gift to the whole delegation, though, rather than solely to Berdyshev. On March 4, 1936, a special badge, the "Voroshilov Rider," was established for those civilians who achieved good results in military training as cavalrymen and women. (Marshal Kliment Voroshilov, People's Commissar for Defense, was extolled by Leyb Kvitko in his children's poem Letter to Voroshilov, whose Russian translation from the Yiddish, by Samuel Marshak, came out in August 1937 with a printrun of one million copies.) According to Godiner, Berdyshev promised the Cossacks to commit himself to forming and training in Novozlatopol a detachment of Voroshilov riders.

In his last, autobiographical novel, My 1930s Years, Melamud once again returned to the events of Jewish and Cossack delegations:

Two national groups, whose reciprocal hatred had a centuries-old history. Jewish children would be scared by Cossacks, and Cossack children were frightened by Jews. The only difference was that Jews were victims of pogroms, while Cossacks were the perpetrators. And suddenly the history brought them together in a completely different way and revealed to each other their real face. Initially, not everything went smoothly in their encounter. I remember how in some Jewish villages people ran away, catching sight of a group of Cossacks dressed in blue riding pants with a red stripe down the side. I also remember how in Tsimlianskaia, when a delegation of our district visited it, one old Cossack, Kirei Ivanovich, said: "Until I see it with my own eyes, I'll never believe that Jews cultivate land, plant wine grapes, and raise stock." 30 
Next year, Kirei Ivanovich, and several other Cossacks, visited the Jewish district. By the end of the visit he was so overwhelmed by what he had seen that he told during the farewell dinner:

\footnotetext{
"I want to ask you to forgive me. My whole life I hated Jews. So, when my son married a Jewish woman in Rostov, I damned him. Now I am telling all of you that I am revoking my condemnation."

Then the milkmaid Rosa Lurye [...] stood up, approached the old Cossack and told him:

"Speaking of that... My daughter married a Cossack in Rostov. Perhaps, he is your son. It means that we are family now. Let's give each other a hug!"31
}

There is no way to tell if Melamud's memoirs describe real events of the 1930s or (most probably) represent a literary remake of the final scenes-the wedding of Roza (a Jewish re-settler) and Kornei (an Amur Cossack) -in the 1936 Soviet talkie Seekers of Happiness, set in Birobidzhan. ${ }^{32}$

The Red Army did not have Ukrainian Cossack units, but the historical importance of Ukrainian Cossackdom was recognized by introducing, in October 1943, the Order of Bohdan (or "Bogdan") Khmelnytskyi, the only Soviet military order named after a non-Russian historical personality. At the same time, the town of Pereiaslav, where in 1654 the so-called Pereiaslav Council of the Russian Tsar Aleksei Mikhailovich and the Ukrainian Cossacks led by Khmelnytskyi had laid the foundation for Ukraine's integration into the Russian state, was renamed in Pereiaslav-Khmelnytskyi. ${ }^{33}$ (Incidentally, Pereiaslav is also known as the birthplace of Sholem Aleichem.) A legendary figure in Ukrainian history, Hetman (Commander) Khmelnytskyi has quite a different reputation in Jewish history: generations after generations of Jews condemned him as a monstrous personality, responsible for the annihilation of whole Jewish communities, most notably in 1648 and 1649. Any mention of Khmelnytskyi would be accompanied by the curse "may his name be blotted out" ("מח שמו וזכרו": yemakh shmoy vezikhroy).

In January 1940, a remarkable academic event took place in Moscow, at the History Institute. The Odessa scholar Saul Borovoi had successfully 
defended his doctoral dissertation on Jewish history in Ukraine. One of the chapters concentrated on the Khmelnytskyi Uprising. Borovoi argued that it was wrong to follow the tradition of presenting the Jewish population as victims of the Ukrainian Cossacks and peasants. Rather, the Jews were part of the general military conflict, supporting predominantly the Polish colonizers, and, as such, were a fair game of the Ukrainian militants. This interpretation of one of the bloodiest pages in modern Jewish history provoked outrage among Yiddish literati, notably the literary historian Isaac Nusinov and the poets Peretz Markish and Shmuel Halkin, who could not accept that-in Halkin's words - the "murderer" Khmelnytskyi was hailed as the leader of the Ukrainian national-liberation movement. ${ }^{34}$

In fact, Borovoi's dissertation was a footnote in Khmelnytskyi's Soviet re-mythologization in the late 1930s and early 1940s, with a play and a film script by the Ukrainian writer Aleksandr Korneichuk at the center of the process under Stalin's personal control. ${ }^{35}$ There is little doubt that Stalin, Korneichuk, and the majority of other politicians and intellectuals involved in the canonization of the legendary Ukrainian figure, did not pursue any anti-Jewish agenda. Rather, in the fall of 1943, when the Red Army was liberating Ukraine, the government sought to send an encouraging message to the second-largest ethnic group of the Soviet population.

In the meantime, the 1943 decision to aggrandize Khmelnytskyi resonated in Jewish circles all over the world. The pro-Soviet press cultivated the image of Cossacks as liberators from the Nazis. For instance, Zishe Weinper, a left-wing American Yiddish poet and activist, had developed this theme in his poem "When a Cossack Rider Came to the Dniepr River." 36 Granted, similar topics had also inspired left-wing literati, including the Canadian poet Sholem Shtern, before October 1943. ${ }^{37}$ Meanwhile, the New York-based Forverts, which was the biggest Yiddish daily, contended that the Soviet government's decree was a step similar to renaming a town after Hitler. Mendel Osherowitch, a Forverts journalist (he also played a leading role in the American Federation of Ukrainian Jews), quoted various sources estimating the number of Jews murdered by Khmelnytskyi's Cossacks at between 100,000 and 650,000. ${ }^{38}$ The Israeli historian Shaul Stampfer, who has analyzed the scale of anti-Jewish violence in seventeenth-century Eastern Europe, comes to the conclusion that the chronicles gave very inflated numbers of victims and that "the impression of destruction was greater than the destruction itself." ${ }^{39}$ Indeed, the "impression" was very strong, and the 
London newspaper Jewish Chronicle commented on the Soviet government's decision:

This man Chmielnitski [sic] was a Cossack Hetman in the seventeenth century and under his direction 300,000 or more Ukrainian Jews were massacred by the Cossacks. Naturally this elevation to the status of a patriot or a hero whose deeds are presumably to be regarded as an inspiring example to all Russians was not a little painful to Jews. It is not surprising, therefore, that the two distinguished representatives of the Jewish Anti-Fascist Committee in Russia-Professor Mikhoels and Lt.-Col Fefer-who are now in London, should have been asked to explain. ${ }^{40}$

The director of the Moscow Yiddish theater, Solomon Mikhoels, and the Yiddish poet Itsik Fefer were winding up their tour of the United States, Canada, Mexico, and Great Britain. On the longest, American leg of the Soviet Jewish representatives' trip, the Cossack topic had already been mentioned in one of Fefer's speeches. The poet, who was referred to as a lieutenant-colonel of the Red Army (during the war many writers had military ranks as political instructors), told a joke that should show the American Jews that their Soviet counterparts had become stronger than the Cossacks, once the most terrifying enemy of Russian Jews:

I was told that a tourist from Argentina came to Birobidjan [sic] once and he stopped to talk with a Jewish settler there.

"How are things going," he asked.

"Very well," answered the Jew from Birobidjan.

"Who are your neighbors," the Argentinean wanted to know.

"Cossacks."

"Cossacks?"

"Sure," said the Jew from Birobidjan, "but we leave them in peace."41

The Jewish Chronicle, however, expected a serious explanation. "Their [Mikhoels and Fefer's] reply that what Chmielnitski [sic] did was to lead a rising of subjugated Ukrainian masses against their Polish oppressors and those whom they believed to be associated with them can scarcely be regarded as very satisfactory." The newspaper also expressed the hope that Soviet Jewish combatants would not "through an act of sheer forgetfulness, be insulted 
by decoration with the order of Bogdan Chmielnitski [sic]." ${ }^{42}$ Nonetheless, a number of Jews were "insulted" by this award and, apart from a couple of unverified cases when Jewish combatants rejected the order, ${ }^{43}$ they, products of Soviet upbringing, either did not know about Khmelnytskyi's historical record or saw the calumnious event as ancient history, with no direct relevance to their world.

Coincidentally, or most probably intentionally, among the first officers honored by the distinction was the Lieutenant Colonel Iosif Kaplun. ${ }^{4}$ Among the Jews decorated by the Order of Bohdan Khmelnytskyi were also the Heroes of the Soviet Union Army General Iakov Kreizer, Colonel General Leontii Kotliar, and Lieutenant General Matvei Vainrub. The poet Boris Slutskii, whose war-time memoirs provide an insight into the interethnic relations in the army, argued that by 1943 soldiers of various nationalities had got used to each other and that their relations became much friendlier than in the earlier stages of the war. He also wrote about Jewish officers who did their utmost to show that Jews were not cowards. One of the bravest officers was a young man, not physically very strong, a philology student at the Kiev University before the war. He volunteered for a reconnaissance detachment, and in the short interval of six months was decorated by four orders, including the Order of Bohdan Khmelnytskyi. Significantly, in Slutskii's memoirs the award is not mentioned as an affront to Jewish combatants. ${ }^{45}$

It is no coincidence that Natan Rybak (1913-78), a Ukrainian writer of Jewish origin and a Soviet person of the same generation as Slutskii (191386), portrayed Khmelnytskyi as a heroic figure in his 1947-53 novel Pereiaslav Council. In general, the absence of the seventeenth-century massacres in the Jews' historical imagination can be seen as a litmus test for Sovietization. In 1943, Lazar Fagelman, a heavyweight among the Forverts writers (in 1962-68 he would edit the paper), wrote about the abyss that had divided the Soviet Jewish and the American Jewish worlds: "Now we have to understand that Soviet Jews differ from us: their habits, values, and manners are different; their vision of life is different; they have a different attitude to people, to the world and to all political, economic, and moral problems." ${ }^{46}$

I have not come across any statistics of Jewish participation in the Red Army cavalry detachments, though it is known that Jewish cavalrymen fought in 
various regiments and divisions, including Cossack ones. Thus, Efim Podoksik served as a private, sergeant, and sergeant major in a Cossack detachment. According to him, he never had problems with being a Jew among non-Jewish cavalrymen. When Mikhail Sholokhov visited his regiment, Podoksik's commanders were happy to show him off to the venerable novelist. ${ }^{47}$

Indeed, a Jewish cavalryman belonged to a rather exotic category of soldiers serving in Cossack units. In fact, I remember very well Matvei Berdyshev, whose wife happened to be one of my mother's sisters. To the best of my knowledge, during the war he was a Red Army officer, a captain, but had nothing to do with Cossacks. Thus, the wartime travails of Zalman were a product of the creative imagination of Khaim Melamud, an old friend of Berdyshev. In general, an ethnic breakdown of the Red Army's Cossack units, if such statistics could be found, would certainly reveal low numbers of Jewish cavalrymen, because such units had been formed in the areas populated by Cossacks. ${ }^{48}$ Jews, on the other hand, predominantly lived in urban areas of Ukraine, Belarus, and Russia and, apart from some enthusiasts (for instance, successful "Voroshilov Riders"), had little to do with riding. No doubt, this is one of the reasons why the realists (even socialist ones) Melamud and Gordon described their fictitious Jewish Cossacks as village dwellers.

The situation was somewhat different with officers of Cossack detachments. Career officers as well as mobilized doctors, political instructors (often teachers in their prewar life), and other categories of reserve officers certainly included some number of Jews. It is illuminating, for instance, that among the officers of the $5^{\text {th }}$ Don Cossack Corps was Vladimir Piatnitskii, whose father Osip (Iosif) Piatnitskii, a leading Bolshevik, had vanished during the Stalinist purges. Vladimir Piatnitskii describes how his father's friends, who survived the Stalinist purges and the war, were shocked to see him in a Cossack uniform and reminded him that his father hated Cossacks, particularly the Don ones. ${ }^{49}$

The topics of Jews' participation in the Red Army and their heroism dominated the communications and correspondence written by the literati of the Jewish Anti-Fascist Committee. ${ }^{50}$ However, stories about Jewish cavalrymen can be counted on the fingers of one hand. For instance, the novelist Hershl Polyanker wrote a documentary story about Avrom Revutski, whom the writer met in one of the regiments fighting in the north Caucuses. In June 1941, Avrom finished secondary school and several days later volunteered to 
a cavalry unit of the Red Army. Although Avrom had previously never sat astride a horse, he soon became a confident rider and a valiant soldier. By the end of the short story, he appears as a seasoned warrior, instructing new recruits before their baptism of fire. ${ }^{51}$

Yet, among the stories that appeared in the newspaper Eynikayt (Unity) of the Jewish Anti-Fascist Committee, more attention was paid to Jewish commanding officers of cavalry regiments and divisions. The journalist Moyni Shulman introduced to readers Colonel Khaim (Efim) Popov, commander of a Kuban Guards Regiment. Granted, the colonel's Jewishness is clear only from his name; otherwise it does not play any role in Shulman's text. ${ }^{52}$ More pronounced is the Jewishness of the commander of a cavalry division, and later of a cavalry corps, General Vladimir Tsetlin. Shmuel Persov, the author of the documentary story "The Glorious Cavalry Man," mentioned that Tsetlin grew up in Odessa, in a proletarian Jewish family, and that he spoke Yiddish. ${ }^{53}$

Biographies of Jewish cavalry generals and colonels often reveal their participation in the First World War and the Civil War, and then a military career in the Red Army. For instance, Vladimir Tsetlin was a soldier in the tsarist army, in the division under the command of General Anton Denikin. During the Civil War, Tsetlin, an officer in the brigade of the Red Army commander Grigory Kotovskii, fought against Denikin's White Guard troops. In the 1930s, he was lucky to be spared during the Stalinist repressions, when tens of thousands of officers and generals, including Jewish ones, were executed or sent to Siberian labor camps.

The ethnicity of the legendary general Lev Dovator, commander of a guard cavalry corps, remains up for debate. The majority of scholars and journalists maintain that Dovator was Jewish, though his Russian biographers and Aron Abramovich, the Israeli authority in the field of Jewish participation in the Red Army, contended that the general was born into a family of Belorussian peasants. ${ }^{54}$ Even if Dovator had nothing to do with Jews, his Jewish legend began to circulate soon after (or even before) his heroic death in December 1941. In the beginning of 1942, Solomon Mikhoels announced that his Yiddish theater, evacuated from Moscow to Tashkent, would stage a play devoted to Dovator, "the Soviet Jewish general who led the Cossack attack on the Nazis." ${ }^{5}$ A volume released in February 1943 by the Soviet embassy in the United States carried the following quote of Mikhoels: "The popular Jewish playwright, David Bergelson, is writing a play for us about 
the talented Jewish cavalry general, Lev Dovator, who covered his name with glory in the present war." ${ }^{\text {"6 }}$ In reality, Bergelson, mainly a novelist, eventually wrote a play set in medieval Italy. ${ }^{57}$

A Red Army commanding officer, an uncle of the protagonist, appears in Anatoly Rybakov's 1979 novel Heavy Sand: “Uncle Misha was mad about horses. He would give his soul for the chance to gallop a horse with a Cossack saddle, or a cavalry saddle or bareback." Rybakov painted this character from life. During the First World War, his sixteen-year-old uncle Misha run away from the shtetl to join a cavalry squadron and then became a Red Army commander. In his analysis of Rybakov's novel, Gary Rosenshield comes to the conclusion, "The uncle achieves what the narrator of Babel's Cossack stories can only dream of: the ability to ride a horse like a Cossack, a guarantee of never being mistaken for a Jew." ${ }^{58}$ It echoes the remark made by one of Isaac Babel's characters: "A Jew who mounts a horse ceases to be a Jew and becomes a Russian." 59

My own experience of growing up with an uncle (also an Uncle Misha, or Meir), who was a career officer and by the end of the war led a regiment in the elite Kantemirov Guards Division, and of meeting many other career officers of that generation, did not leave me with an impression that any of them sought to hide their Jewishness. Uncle Meir was a diehard Communist and a bitter anti-Zionist, but he spoke Yiddish at home and, generally, remained a proud Jew. No doubt, such people did not mount a horse or (more typically) become members of tank or gun crews in order to be Russians-never mind that the Soviet bureaucratic system made it next to impossible to change the nationality in their documents. In any case, their motivations were, as a rule, similar to the motivations of their Russian, Ukrainian and other Soviet peers, namely to become a Red Army officer, a status that was very high in Soviet society. As for cavalry or Cossack soldiers and officers, their heroic image was particularly attractive, both for Jews and non-Jews.

In other words, it is important not to confuse two essentially different agendas: first, that of Soviet Jews, who intentionally or unwittingly found themselves in the Red Army; second, that of Soviet Jewish-most notably Yiddish - writers who portrayed the events of the Great Patriotic War. While personal agendas might have specifically Jewish elements, such as setting an example of Jewish bravery or using the military career as a route to complete assimilation, Soviet Jewish writers "combine[d] writing about the Holocaust in the strict sense of the word with writing about resistance" ${ }^{10}$ and sought to 
emphasize heroism in their Jewish characters. Cavalrymen appear in their oeuvre as one of the ultimate symbols of Jewish heroic resistance.

In the story "Flora," written by Der Nister in 1946, the protagonists, heroic Jewish partisans Berl and Flora, dance "in the Cossack manner" at the reception given by "a Jewish social organization" (presumably, the Jewish Anti-Fascist Committee) on May 9, 1945:

In a non-Jewish way, he gave her a lift with his right hand, on the right side of her back, going in a trot and a circle around her. She smiled, yielded, and danced with him.

Then, he exchanged the right hand for the left. Holding the left side of her back, he performed the same as before-this time with bended knees, crouched at half his height and dancing as if seated. ${ }^{61}$

Thus, a Cossack dance became a dance of victorious Soviet Jews, whose symbiosis with hereditary Russian warriors did not denationalize them (significantly, Berl and Flora celebrated the victory at a Jewish organization), but allowed them to achieve an extraordinary level of heroism. Socialist realist writers continued to extol this symbiosis in the remaining years of the Soviet Union's existence.

\section{Notes}

1 See, for instance, the Russian books by Ikhil Falikman: Obrechennye berut oruzhie (1959); Chernyi veter (1968 and 1974); Ogon' i pepel (1977); by Mikhail Lev: Partizanskie tropy (1958); Sud posle prigovora (1982); Esli by ne moi druz'ia... (1968, 1976, and 1986); Izbrannoe (1983); Dlinnye teni (1989).

2 For the periods of the Jewish Antifascist Committee and the Sovetish Heymland, see Shimon Redlich, Propaganda and Nationalism in Wartime Russia: The Jewish Antifascist Committee in the USSR, 1941-1948 (Boulder, CO: East European Quarterly, 1988); Joshua Rubenstein and Vladimir P. Naumov, eds., Stalin's Secret Pogrom: The Postwar Inquisition of the Jewish Anti-Fascist Committee (New Haven and London: Yale University Press, 2001); Gennady Estraikh, Yiddish in the Cold War (Oxford: Legenda, 2008).

3 Priscilla Johnson and Leopold Labedz, Khrushchev and the Arts: The Politics of Soviet Culture, 1962-1964 (Cambridge, MA: MIT Press, 1965), 181-83.

4 The novel first appeared in the Moscow Russian literary monthly magazine Oktiabr' 7- 9 (1978).

5 Gennady Estraikh, "Literary Images of the 'Birobidzhan Generation"' Slavic Almanac 11.1 (2005): 91. 
6 Rubenstein and Naumov, eds., Stalin's Secret Pogrom, 487.

7 S. Ansky, The Enemy at His Pleasure: A Journey Through the Jewish Pale of Settlement During World War I, ed. and trans. Joachim Neugroschel (New York: Metropolitan Books, 2003), 6. See also Gennady Estraikh, "Viewing World War I from across the Ocean: The New York Yiddish Daily 'Forverts' on the Plight of East European Jews," Jews and Slavs 23 (2013): 371-84.

8 Oleg V. Budnitskii, Rossiiskie evrei mezhdu krasnymi i belymi, 1917-1920 (Moscow: Rosspen, 2005), 286.

9 For Melamud and Gordon, see, e.g., Mikhail Krutikov, "Soviet Yiddish Literature of the 1960s-80s and its Russian Translations," in Yiddish in the Contemporary World, ed. Gennady Estraikh and Mikhail Krutikov (Oxford: Legenda, 1999), 80-82; Gennady Estraikh, "Shmuel Godiner: A Yiddish Writer in 'the Ocean of Russian Literature", in The Yiddish Presence in European Literature: Inspiration and Interaction, ed. Joseph Sherman and Ritchie Robertson (Oxford: Legenda, 2005), 134-51. Shmuel Gordon, Vechnaia mera (Moscow: Sovetskii Pisatel', 1981), 189.

11 Shmuel Gordon, Milkhome-tsayt (Moscow: Emes, 1946), 7-12. Gordon, Milkhome-tsayt, 8. See Gennady Estraikh, “From 'Green Fields' to 'Red Fields': Peretz Hirschbein’s Soviet Sojourn, 1928-1929," Jews in Russia and Eastern Europe 56 (2006): 61. Gennady Estraikh, "Pig-breeding, Shiksas, and Other Goyish Themes in Soviet Yiddish Literature and Life," Symposium 57.3 (2003): 164. Israel Bartal, "Kazak i beduin: novyi mir natsional'nykh obrazov," Vestnik Evreiskogo universiteta 6.24 (2001): 263-78. Judith Deutsh Kornblatt, The Cossack Hero in Russian Literature: A Study in Cultural Mythology (Madison: University of Wisconsin Press, 1992), 120.

Il'ia Dubinskii, Trubachi trubiat trevogu (Moscow: Voenizdat, 1962); Abraham Pribluda, "Yidishe komandirn tsvishn di sovetishe kozakn," Morgn-Frayhayt, September 26, 1973: 19; October 7, 1973: 5; October 9, 1973: 3; November 4, 1973: 3. (Dr. Simon A. Prussin kindly sent me copies of these newspaper articles). Estraikh, "From 'Green Fields' to 'Red Fields,” 68. See Estraikh, "Literary Images of the 'Birobidzhan Generation,” 83.

21 Felix Rynsky, "Jews and Cossacks in the Jewish Autonomous Region," Refuge 12.4 (1992): 21.

22 Lion Feuchtwanger, Moscow, 1937: My Visit Described for My Friends (New York: The Viking Press, 1937), 89.

23 Peter Holquist, "'Conduct Merciless Mass Terror': Decossackization on the Don, 1919," Cahiers du Monde russe 38.1-2 (1997): 127-62.

24 Benjamin Nathans, Beyond the Pale: The Jewish Encounter with Late Imperial Russia (Berkeley and Los Angeles: University of California Press, 2002), 78, 311.

25 Gennady Estraikh, “The Soviet Shtetl in the 1920s," Polin: Studies in Polish Jewry 17 (2004): 203. 
26 Albert Seaton, The Horsemen of the Steppes: The Story of the Cossacks (New York: Barnes \& Noble, 1996), 234.

27 See the two pamphlet editions: Samuil [Shmuel] Godiner and D. Lipshits, Vstrecha $v$ Tsymle: Dogovor druzhby kolkhoznikov kazakov i evreev (Moscow: Der Emes, 1936); Shmuel Godiner, Der yontev fun frayntshaft (Moscow: Der Emes, 1939). 'Bogdan Khmel'nitskii' (1941),' Istoriohrafichni doslidzhennia v Ukraïni 18 (2008): 427-55. Zishe Weinper, "Ven k
November 6, 1943, 3, 1 . Iauza/Eksmo, 2007), 6-9. 
Dov-Ber Kerler, "Eynikayt during the War," in Why Didn't They Shout?: American and International Journalism during the Holocaust, ed. Robert Moses Shapiro (New York: Yeshiva University Press, 2003), 225.

51 Hershl Polyanker, “Der rayter Avrom Revutski," Eynikayt, October 15, 1942, 2.

52 Moyni Shulman, "Der kazakisher polkovnik Khaim Popov," Eynikayt, October 19, 1944, 3.

53 Shmuel Persov, “Der rumfuler kavalerist," Eynikayt, May 31, 1945, 3.

54 Aron Abramovich, $V$ reshaiushchei voine: uchastie i rol' evreev SSSR $v$ voine protiv natsizma (St. Petersburg: DEAN, 1999), 31. See also, e.g., Reuben Ainsztein, "The War Record of Soviet Jewry," Jewish Social Studies 28.1 (1966): 10.

55 "Soviet Jews Honour General Dovator: Hero Who Beat Nazi Blitz," Jewish Chronicle (London), April 24, 1942, 1.

56 Soviet Art in Wartime: Information Bulletin. Special Supplement (Washington, DC: Embassy of the USSR, 1943), 48.

57 Jeffrey Veidlinger, “Du lebst, mayn folk': Bergelson's Play Prints Ruveni in Historical Context," in David Bergelson: From Modernism to Socialist Realism, ed. Joseph Sherman and Gennady Estraikh (Oxford: Legenda, 2007), 269-84.

58 Gary Rosenshield, "Socialist Realism and the Holocaust: Jewish Life and Death in Anatoly Rybakov's Heavy Sand," PMLA: Publications of the Modern Language Association of America 111.2 (March 1996): 245; Anatolii Rybakov, Roman-vospominanie (Moscow: Vagrius: 2005), 13-16.

59 Richard William Hallett, Isaac Babel (New York: Ungar, 1973), 37.

60 Lukasz Hirszowicz, "The Holocaust in the Soviet Mirror," in The Holocaust in the Soviet Union: Studies and Sources on the Destruction of the Jews in the Nazi-Occupied Territories of the USSR, 1941-1945, ed. Lucjan Dobroszycki and Jeffrey S. Gurock (Armonk, NY: M. E. Sharpe, 1993), 52.

61 Der Nister, Regrowth: Seven Tales of Jewish Life Before, During, and After Nazi Occupation, translated from Yiddish by Erik Butler (Evanston: Northwestern University Press, 2011), 148, 153. 